\title{
INVESTIGATION OF SOCIAL ECONOMIC VARIABLES AS DETERMINANTS OF PREFERRED SOCIAL NETWORKING SITES
}

\author{
Sarah Gambo \\ Taraba State University Jalingo \\ gamssarah@gamail.com \\ Coleman Fidelis Essien \\ Eastern Mediterranean University North Cyprus \\ 18600125@students.emu.edu.tr \\ Ochanya Ajii \\ Eastern Mediterranean University North Cyprus \\ otsanyajii@gmail.com \\ Shem Woyopwa \\ Taraba State University Jalingo \\ Shem.woyopwa@yahoo.com
}

\begin{abstract}
This paper sought to investigate the social economic variables as determinants of preferred social networking sites by International Students of Eastern Mediterranean University in North Cyprus. Social Networking Sites (SNS) platforms are gradually replacing the known, traditional means of communication as a result of new improved communication systems. The application of Social Networking Sites in our present generation is inevitable due to its efficiency and capability of connecting the whole globe in a second.These Social Networking Sites have made great contribution towards socio-cultural and economic development thereby re-ordering the world and making it a global village. Two platforms are considered in this research; Facebook and Instagram to know the right prediction based on the demography of users. The research design is survey, while questionnaire was used as the instrument of data collection. Uses and Gratifications Theory is adopted as theoretical framework. Using SPSS for the analysis, the CHAID method with the help of a tree diagram shows that some of the demographic factors are better predictors of social media platforms when it comes to communication with specific places.
\end{abstract}

Keywords: Social, Economy, Social Networking sites, Prediction

\section{INTRODUCTION}

The use of social media for interaction among young generation has really been impactful. Social media have altered interpersonal communication;more people now participate in online activities more than ever(Saul, 2016). Arikewuyo and Abdulbaqi (2013) opined that the availability and exposure that comes with this new technology Social Networking Sites (SNS) have great impact directly or indirectly on the social media users.

Bicen and Cavus (2010) assert that preference in the use of (SNSs) involves communicating online using a particular media platform. However, there are different platforms that can be used to achieve specific purposes. A similar understanding was expressed by Korhan \& Ersoy(2016) when they posited that the availability and the functionality of each platform results in selecting the platform that best satisfies the users' need because their motivation and their assessments of the platforms are best known to them. 
Re-echoing these views, Kircaburun, Alhabash, Tosuntaş\& Griffiths, (2018) say that the uses and gratification of each platform is based on some factors such as: the motives of the user, individual differences; social economic factors, personality and popularity of the social media sites. This implies that a user's choice for a platform can be influenced by many variables, ranging from his economic to social status. This tends to pose a lot of challenges because meeting new friends and making effort to get acquainted with them are said to be associated with problems of using the social media at the users' disposal. (Bicen\&Cavus 2010; Atkin, Hunt, \& Lin, 2015)

Many researches have been conducted on preference of sites. For example, a study was conducted on preference by intensity of usage. Here, four platforms were compared based on students' motivation with online participants spending most time on Instagram, Snapchat, Facebook and Twitter (Alhabash\& Ma, 2017). It was revealed that these participants in spite of their familiarity and proficiency in the use of these four different platforms still encountered difficulties deciding on which sites they can use for their needs and find gratification. It is against this back drop that this study is undertaken to ascertain the predictor that is most likely responsible for the choice of use and preference of SNSs using tree decisions.

In the last two decades (2005-2019), the Pew Research Center has been carrying out demographic surveys on social media users in the United States. Some of their surveys contain important statistics on the demographics of SNS Users especially those on Facebook and Instagram. A 2012 Pew survey on social media demographics uncovered some rich statistics on gender, age and racial distribution of users of two of the SNS in this review (Facebook and Instagram) (Duggan \& Brenner, 2013). Sixty-seven percent of internet users (comprising women and adults ages 18-29) use Facebook while only 13\% (comprising adults ages 18-29, Latinos, women and urban residents) use Instagram.

In 2015, Pew Research Center added some more demographic component on its social media users' demographic component including race, level of education and level of income for Facebook. Facebook still maintained the lead among American adult internet users with 72\% of users and Instagram rose to 28\% (Duggan, 2015). Young adults ages from 18-29 and Black, Non-Hispanic had the highest number of users among other demographic categories with 55\% and $47 \%$ Instagram users. Yet predictor is our major concern over the preference of use of social media.

To this effect, Facebook and Instagram are used for this study based on the argument presented by Alhabash and Ma (2017), that there are newer and old social media from which users can choose from, other platforms mentioned which users can choose from are Twitter and Snapchat.

\section{BRIEF HISTORY OF FACEBOOK AND INSTAGRAM}

The history of Facebook is linked to the journey of Mark Zuckerberg, a 23-year-old Harvard University Psychology student experimenting on social networking in computer programming. It was launched globally in February 2004 as "The Facebook" with an initial subscription covering more than half of the Harvard undergraduate student population in the space of a month (Phillips, 2007; McFadden, 2019). Together with co-founders Chris Hughes, Eduardo Saverin, and Dustin Moskovitz, Zuckerberg extended the subscription to three other US elite university campuses: Yale, Stanford and Columbia (Greiner et al, 2019) The present name (Facebook) was adopted in August 2005 after the purchase of 
Facebook.com for the sum of $\$ 200,000$ (Phillips, 2007). Facebook became opened for global subscription on 26 September 2006 (Barr, 2018). It emerged as the biggest global social network in 2012 with over a billion users (Hall, 2019).

Instagram on the other hand was co-founded in San Francisco by Kevin Systrom and Mike Krieger. It was launched on 6 October 2010 (Instagram, 2019). The history of Instagram began when Systrom embarked on a project to create an app dubbed 'Burbn' designed as a mobile web app to help people to check-in, share pictures and their plans. The project was not successful due to the confusing nature of the app employed entirely by users to share all types of photos (Harrison, 2018). Notwithstanding, Systrom met with two venture capital firms in Silicon Valley (Adreessen Horowitz and Baseline Ventures) to discuss his project weeks after the creation of Burbn and was able to raise seed capital to the tune of $\$ 500,000$ for his project (Woods, 2013) which was later launched.

\section{STATEMENT OF PROBLEM}

There are different platforms used by various people for communication purposes; it is however, difficult to determine or predict the particular demographic factor responsible for their choice of the platform. This study therefore, explores the various demographic variables such as age, gender, educational level, and marital status and seeks to determine the ones that can be used to predict or determine the preference for a platform or SNSs used by international students in Eastern Mediterranean University (EMU) when communicating with family members, friends and other international acquaintances while in school in the year 2020.

\section{RESEARCH OBJECTIVES}

Based on the selected demographic factor, the research is aimed at finding out the following:

$>$ The most predictor/predictors that determine the choice for the preferred SNS (Facebook/Instagram) when communicating with families and friends among international students in EMU in the 2020 fall academic session.

$>$ The most predictor/predictors used to determine the two social media (Facebook/ Instagram) when relating with other international acquaintances during the 2020 winter semester in EMU, North Cyprus.

\section{RESEARCH QUESTIONS}

RQ.1 Which are the most predictor/predictors that determine the choice for the preferred SNS (Facebook/Instagram) when communicating with families and friends among international students in EMU in the 2020 fall academic session?

RQ.2 Which are the most predictor/predictors used to determine the two social media (Facebook/ Instagram) when relating with other international acquaintances during the 2020 fall semester in EMU, North Cyprus?

\section{REVIEW OF RELATED LITERATURE}

The advancement in the use of technology for communication has also made different forms of communication to be used for interactive purposes especially the upgrade and changes that comes with the webs of technology. There are various factors that play vital roles in the choice of media platform while some are Psychosocial; others are influenced by demographic variables (Clark, Algoe\& Green, 2018). Physiological factors that influence the choice of SNS include; economic, technology and culture.(Aksoy, Van Riel, Kandampully, Bolton, Parasuraman, Hoefnagels, \&Solnet, 2013). 
Psychosocial and physiological factors come into play when students select an SNS. Hughes, Rowe, Batey\& Lee (2012), argue that personality and differential relationships correlate with online socializing. This is to say that a person's openness, gender, age, sociability, agreeableness and need for cognition play an important role on the level and extend of information exchange. In general, preference is brought about by recommendation systems where by a network diffusion plays an important role (Rogers 2014).

The precision of a predictable outcome becomes blissful and the choices of a rational option turn out to be probabilistic yet variability of the outcome is a unique challenge students have to overcome. Kaplan \& Miller (1987), explain that individuals and groups generally change their preferences after discussion. The precision of a predictable outcome becomes blissful and the choices of a rational option turn out to be probabilistic yet variability of the outcome is a unique challenge students have to overcome. De Dreu, Nijstad, \& Van Knippenberg, (2008), suggest that social motivation and epistemic motivation influences the interaction and the decision-making process. However, the outcome of any interaction in a group in normative decisions can never be weighed nor be deterministic in nature thus bring about uncertainty.

Hinsz, (1999) comes to a conclusion that decision outcomes are also based on compromise instead of consensus processes on occurrence of discrete choices, based on preferences. Some platforms have been found to be very addictive in nature; however, the Social Media are used to send posts and peruse posting by other users (Huang \& Su 2018).

\section{THEORETICAL FRAMEWORK}

This study is anchored on Uses and Gratifications Theory (UGT). It is a theory based on television viewing usage. The Uses and Gratification Theory was and still remains one of the essential theories of communication used especially in the $21^{\text {st }}$ era (LaRose \& Eastin, 2004). The Theory talks about the users choice in desiring one or more gratifications in a specific media (Katz, Blumler,\& Gurevitch, 11973-1974). The Uses and Gratification Theory gives perspectives on users' motivation and choice of a platform to achieve needed gratification (Katz, 1957).

In this age of advancement in technology, more attention have been given to the uses and gratification theory (Dias, 2016). For instance, communication has shifted from the mainstream media to individual form where they are demassified, using a lot of platforms for users gratification; some are direct and instant messages from mobiles while others are applications such as whatsApp.

The intrusive nature of the media have added to the uses and gratifications by users, aiding the audience to have more choices and preference of platforms. Thus, the media is capable of influencing the users over their selecton of a platform through the diverse channels at their disposal (Atkin, Hunt, \& Lin, 2015).

The social media which encompass SNSs are seen as very vital area in our lives today.(Garcia-domingo, Aranda, \& Fuentes, 2017). This is because many scholars have attested to the fact that social media is used by various people for their personal or group gratification as emphasized by Whiting and Williams (2013). 
Scholars such as Wei, Lin, Lu, \& Chuang(2015); Froget, Baghestan, \& Asfaranjan, (2013); Karimi, Khodabandelou, \& Ahmad, (2014) have argued that users stick to SNSs because it assist in meeting "users" (students) need for information, need for entertainment, maintaining relationships, meeting new people and sharing informaton with them as well as keeping connected with them.

According to a research conducted in Mauritius, the social media platforms can be used for eight (8) different motives to predict the application of Facebook as a platform. Using 392 Facebook users in an online survey, the study revealed that the platform was used for meeting people, for entertainment and maintaining relationships with friends. The Facebook help a lot in interaction during social events and it is excellent for sharing the content produced by the media. The Facebook can be used among other things for inquiry, employment, discussion purposes and for information. Thus, these eight factors are found to be positively correlated with Facebook (Froget, Baghestan, \& Asfaranjan, 2013).

According to Hunt, Atkin, \& Krishnan, (2012) the uses and gratification theory is relevant in both mainstream and social media hence its application to this study.

Gratification always comes with Gratification sought (GS) with the use of the media and the media expectation (ME) gratification which is obtained (GO) as the media serves the user. This is given in the following formula: GS+ ME+GO with reference to the work they conducted to ascertain the gratification obtained when they use the SNSs of their choice (Heravi, Mubarak \& Choo, (2018).

Weimann, Gabriel, Nirit, Germaw, Maya Mazor and Ravid (2014), in their submission described media users as no longer audience as the then form of communication permits but are regarded as users because of their involvement which is described as being active. Tools applied permits User Generated Contents of such activities.

And most of the users on SNSs are fulfilling the submissions observed by Ruggierro (2000) that users operate based on the demassification nature, assynchroneity and the interactive nature of the media which is social in nature tied to the assumption of the uses and gratifications that users are at liberty to choose from the media available and having the knowledge that these media compete with each other thus the need to ascertain the right predictor based on demographics f users.

\section{METHODOLOGY}

The survey research method was used to achieve the objectives of the study, from which meaningful conclusion can be drawn from information collected from the respondents (Ponto, 2015). Survey research makes use of different ways as means of collecting data which can be through questionnaire or conducting interview. The research instrument were administerd by the researchers/researcher who are involve in conducting the research, thus the items in the questionnaire, are aimed at answering the research objectives. Therefore, the questions must reflect what is obtainanble as the objectives, questions are grouped into different segments with the questions that are dependable research instruments (Dillman, Smyth, \& Christian , 2014).

The tools employed for this study is a self-in-house questionnaire designed by the authors capable of giving answers to the research at hand, using quantitative research.

The first part of the questionnaire is the demographics, and the second part is the platform preference, hours spend and years of use of each platform are considered. 
Respondents are students from the Eastern Mediterranean University, Turkish Republic of Northern Cyprus (EMU, TRNC), irrespective of their age, gender and marital status, students are sampled from all the faculties in EMU, during the Fall semester for the year 2020 to be specific January and February ending. Considering the number of international students in Eastern Mediterranean University (EMU), they are 18,205 for the 2019/2020 academic session in fall semester; the population serves as a good world view for the research to be conducted, hence the sample size is taken from the population (About EMU, 2019).

Although there are a lot of studies that opined that if sample size is chosen from $10 \%$ of the total population thus this work depend on the submission that in some cases the actual sample size will be very difficult to be considered, hence the aims of the researcher and the type of the statistical manipulation can be chosen to carry out a research (Taherdoost, 2017). On this ground, this work will consider 400 EMU students since it is large enough to serve the purpose of the research and almost all the students are on the two platforms or the other hence, any students stands the chance of being chosen based on chart and graph of (Krejcie $\&$ Morgan, 1970). Given that: $=X^{2} N P(1-P)+d^{2}(N-1)+X^{2} P(1-P)$ (Krejcie \& Morgan, 1970). Where; $x^{2}=$ Chi square value at $5 \%$ level of significance (95\% confidence level) which is 3.841 and $\mathrm{N}=$ population size and $\mathrm{P}$ is the population proportion which is $50 \%$ of the population and $\mathrm{d}=$ is the degree of accuracy or level of precision (5\%). Although the number of those to be sampled stood at 375 to 380,400 serves as the sample size by the researchers hence larger number in quantitative research gives more accurate results than lower figures based on law of large numbers which states that bigger samples are better (Lohmeier, 2012).

Simple random sampling was employed, where everyone stands the chance of being chosen. This is a probability sampling method where each participant is chosen by chance and randomly selected thus, it is termed as an unbiased sampling (Agresti, 2008).

In-house questionnaire was designed by the researcher to collect the data. The questionnaire serves as a means of linking up with the respondents this also help the respondents to be sure that they are guaranteed of their confidentiality, personality and their identity on the process of information gathering (Brace, 2008).

The questionnaire drafted serve as a guide to assist the researcher to carefully answer all the research questions put in place for testing. This serves as a clear guide for understanding the aim and the objectives of the study.

Using the tree decision for the analysis this is because it is good for classification and estimation, data description and estimation, thus it can be applied for data reduction in a dimension fit into the group of non-parametric procedures (Milanović\&Stamenković, 2016). Decision tree is structured in a hierarchical manner for the data in groups, referred to as nodes join together by branches of the tree.

\section{DATA PRESENTATION AND ANALYSIS}

Based on the research questions posed for the research, the research tends to answer the best predictor when students communicate with their family members thus; the result is presented as follows: 
Volume 1 Number 2

Four hundred and ten (410) copies of questionnaire were administered, only 400 were retrieved from the participants, based on the questions that are accurately answered and the questionnaire that the information are complete, it is on this basis that the 400 was considered valid for the analysis. Thus the return rate is at $97.6 \%$ which signifies that the return rate is good for the analysis.

\section{DEMOGRAPHIC CHARACTERISTICS OF RESPONDENTS}

Under the demographics of users, some of the variables are merge to make the work more concise and presentable thus they are under the analysis as that can be found on the tables below:

Table 1: Demographic of Respondents

\begin{tabular}{|l|l|l|l|}
\hline \multirow{4}{*}{ Gender } & Category & Frequency & $\begin{array}{l}\text { Percentage } \\
\%\end{array}$ \\
\hline \multirow{5}{*}{ Age } & Female & 238 & 59.5 \\
\cline { 2 - 4 } & Male & 162 & 40.5 \\
\hline \multirow{5}{*}{ Educational Background } & $18-22$ & 143 & 35.8 \\
\cline { 2 - 4 } & $23-27$ & 147 & 36.8 \\
\cline { 2 - 4 } & $28-32$ & 60 & 15.0 \\
\cline { 2 - 4 } & 33 and above & 50 & 12.5 \\
\cline { 2 - 4 } & Undergraduate & 243 & 60.8 \\
\cline { 2 - 4 } & Masters & 92 & 23.0 \\
\hline Faculty & Ph.D. & 65 & 16.3 \\
\cline { 2 - 4 } & Architecture & 21 & 5.3 \\
\cline { 2 - 4 } & Arts and Science & 63 & 15.8 \\
\cline { 2 - 4 } & Business and Economics & 64 & 16.0 \\
\hline \multirow{5}{*}{$\begin{array}{l}\text { Marital status } \\
\text { using most when } \\
\text { communicating? }\end{array}$} & Communication and Media & 41 & 10.3 \\
\hline \multirow{2}{*}{\begin{tabular}{l} 
Which SNS do you prefer \\
\cline { 2 - 4 }
\end{tabular}} & Single & 215 & 53.8 \\
\cline { 2 - 4 } & Married & 61 & 15.3 \\
\cline { 2 - 4 } & Instagram & 285 & 71.3 \\
\hline
\end{tabular}

With regards to the gender of the respondents, $(n=238 ; 59.5 \%)$ are females while males are $(n=162 ; 40.5 \%)$, respondents were within ages $18-23(n=143 ; 35.8 \%), 24-29(n=147$; $36.8 \%)$ and $30-35(n=60 ; 15.0 \%)$, and $30-35(n=50 ; 12.5 \%)$. While accessing the educational background of the respondents $(n=243 ; 60.8 \%)$ are undergraduate, $(n=92$; $23.0 \%)$ are masters students while $(n=65 ; 16.3 \%)$ are Ph.D. students.

The respondents faculty varied Architecture $(n=21 ; 5.3 \%),(n=63 ; 15.8 \%)$ Arts and Science, $(n=64 ; 16.0 \%)$ Business and Economics, $(n=41 ; 10.3 \%)$ Communication and Media Studies, $(n=8 ; 2.0 \%)$ Dentistry, $(n=18 ; 4.5 \%)$ Education, $(n=64 ; 16.0 \%)$ Engineering, $(n=30 ; 7.5 \%)$ Heath Sciences, $(n=35 ; 8.8 \%)$ Pharmacy, and $(n=20 ; 5.0 \%)$ Tourism and Hospitality Management, 
With regards to marital status of the respondents are $(n=215 ; 53.8 \%)$ single, $(n=114$; $28.5 \%)$ in a relationship, $(n=61 ; 15.3 \%)$ are married, $(n=6 ; 1.5 \%)$ are divorced, $(n=4$; $1.0 \%$ ) fall in the category of others.

Table 2: Inquiry about SNS Use

\section{Category}

How long have you been using Facebook

$\begin{array}{lll}\text { 0-11 Months } & 22 & 5.5 \% \\ \text { 1- 2 years } & 74 & 18.5 \% \\ \text { 3-4 years } & 64 & 16.0 \% \\ \text { 5-6 years } & 88 & 22.0 \% \\ \text { 7 years and above } & 152 & 38.0 \%\end{array}$

How long have you been using Instagram

0 to less than an hour.

16

$4.0 \%$

1 hour- 2hours

111

$27.8 \%$

3-4 hours

120

$30.0 \%$

5-6 hours

98

$24.5 \%$

7 hours and above

55

$13.8 \%$

How long do you stay connected on Facebook

How long do you stay connected on Instagram

0 to less than an hour 55

$13.8 \%$

1 hour- 2hours

208

$52.0 \%$

3-4 hours

86

$21.5 \%$

5-6 hours

30

$7.5 \%$

7 hours and above

21

$5.3 \%$

0 to 59 minutes

$30 \quad 7.5 \%$

1 hour- 2hours

$174 \quad 43.5 \%$

3-4 hours

$124 \quad 31.0 \%$

5-6 hours

$47 \quad 11.8 \%$

7 hours and above

Among the platforms you use for communication, which one do you prefer to use when communicating with?

Places and people like...

Family and Friends (People Facebook back home).

People in North Cyprus (host community).
Instagram

Facebook

210

$52.5 \%$

190

$47.5 \%$

136 
Volume 1 Number 2

$\begin{array}{llll} & \text { Instagram } & 264 & 66.0 \% \\ \begin{array}{lll}\text { Others (international } \\ \text { acquaintances). }\end{array} & \text { Facebook } & 143 & 35.8 \% \\ & \text { Instagram } & 257 & 64.3 \%\end{array}$

Which strategy do you prefer to use mostly when you want to reduce uncertainty on social networking sites?

I observe and ignore

messages on SNSs because

it is not important (passive).

I sometimes ask other

128

$32.0 \%$

people who are my friends

on the platform (active).

I ask the fellow who is

46

$11.5 \%$

directly involved

(Interactive).

Sometimes I become

(extremely-active) by

checking through my

followers' wall

$31.0 \%$

Respondents were asked how long they have been using Facebook, answers ranged between 0 -11 Months $(n=22 ; 5.5 \%), 1-2$ years $(n=74 ; 18.5 \%), 3-4$ years $(n=64 ; 16.0 \%), 5-6$ years $(n=88 ; 22.0 \%)$, and 7 years and above $(n=152 ; 38.0 \%)$. While accessing how long respondents have been using Instagram, they say 0 to less than an hour $(n=16 ; 4.0 \%), 1$ hour-2hours $(n=111 ; 27.8 \%), 3-4$ hours $(n=120 ; 30.0 \%), 5-6$ hours $(n=98 ; 24.5 \%), 7$ hours and above $(n=55 ; 13.8 \%)$.

Also respondents answered how long they stay connected on Facebook, answers ranged between 0 to less than an hour $(n=55 ; 13.8 \%), 1$ hour- 2hours $(n=208 ; 52.0 \%), 3-4$ hours $(n$ $=86 ; 21.5 \%), 5-6$ hours $(n=30 ; 7.5 \%)$, and 7 hours and above $(n=21 ; 5.3 \%)$. With regards understanding how long respondents stay connected on Instagram 0 to 59 minutes say $(n=$ $30 ; 7.5 \%), 1$ hour- 2 hours representing $(n=174 ; 43.5 \%), \quad 3-4$ hours representing $(n=124$; $31.0 \%)$, 5-6 hours representing $(n=47 ; 11.8 \%)$, and 7 hours and above representing $(n=25$; $6.3 \%)$.

Among the platforms used for communication, respondents were asked which one they prefer to use when communicating with while interacting with people. While communicating with family and Friends (People back home) those who use Facebook are $(n=210 ; 52.5 \%)$ while those who use Instagram are $(n=190 ; 47.5 \%)$. While communicating with people in North Cyprus (host community) those who use Facebook are $(n=136 ; 34.0 \%)$ while those who use Instagram are $(n=264 ; 66.0 \%)$. Those who communicate with other categories of people like (international acquaintances) and use Facebook are $(n=143 ; 35.8 \%)$, while those who use Instagram are $(n=257 ; 64.3 \%)$.

TABLE 3

Tree Table

\begin{tabular}{|l|l|l|l|l|l|l|}
\hline No & Facebook & Instagram & Total & Predic & Pare & Primary Independent Variable \\
\cline { 2 - 6 }
\end{tabular}


NNAMDI AZIKIWE UNIVERSITY Journal of COMUUNICATION AND MEDIA STUDIES

Volume 1 Number 2

\begin{tabular}{|c|c|c|c|c|c|c|c|c|c|c|c|c|c|}
\hline de & $\mathrm{N}$ & $\begin{array}{c}\text { Percen } \\
\mathrm{t}\end{array}$ & $\mathrm{N}$ & $\begin{array}{c}\text { Percen } \\
t\end{array}$ & $\mathrm{~N}$ & $\begin{array}{c}\text { Percen } \\
t\end{array}$ & $\begin{array}{c}\text { ted } \\
\text { Categ } \\
\text { ory }\end{array}$ & $\begin{array}{c}\mathrm{nt} \\
\text { Nod } \\
\mathrm{e}\end{array}$ & Variable & Sig. ${ }^{a}$ & $\begin{array}{l}\text { Chi- } \\
\text { Square }\end{array}$ & df & $\begin{array}{c}\text { Split } \\
\text { Values }\end{array}$ \\
\hline 0 & 250 & $55.7 \%$ & 199 & $44.3 \%$ & 449 & $\begin{array}{r}100.0 \\
\%\end{array}$ & $\begin{array}{l}\text { Faceb } \\
\text { ook }\end{array}$ & & & & & & \\
\hline 1 & 128 & $71.1 \%$ & 52 & $28.9 \%$ & 180 & $40.1 \%$ & $\begin{array}{l}\text { Faceb } \\
\text { ook }\end{array}$ & 0 & $\begin{array}{l}\text { Educationa } \\
1 \text { level }\end{array}$ & .000 & 28.994 & 1 & $\begin{array}{l}\text { Masters; } \\
\text { Ph.D }\end{array}$ \\
\hline 2 & 122 & $45.4 \%$ & 147 & $54.6 \%$ & 269 & $59.9 \%$ & $\begin{array}{l}\text { Instagr } \\
\text { am }\end{array}$ & 0 & $\begin{array}{l}\text { Educationa } \\
1 \text { level }\end{array}$ & .000 & 28.994 & 1 & $\begin{array}{l}\text { Undergra } \\
\text { duate }\end{array}$ \\
\hline 3 & 79 & $80.6 \%$ & 19 & $19.4 \%$ & 98 & $21.8 \%$ & $\begin{array}{l}\text { Faceb } \\
\text { ook }\end{array}$ & 1 & Gender & .002 & 9.453 & 1 & Male \\
\hline 4 & 49 & $59.8 \%$ & 33 & $40.2 \%$ & 82 & $18.3 \%$ & $\begin{array}{l}\text { Faceb } \\
\text { ook }\end{array}$ & 1 & Gender & .002 & 9.453 & 1 & Female \\
\hline 5 & 81 & $50.9 \%$ & 78 & $49.1 \%$ & 159 & $35.4 \%$ & $\begin{array}{l}\text { Faceb } \\
\text { ook }\end{array}$ & 2 & Gender & .027 & 4.903 & 1 & Male \\
\hline 6 & 41 & $37.3 \%$ & 69 & $62.7 \%$ & 110 & $24.5 \%$ & $\begin{array}{l}\text { Instagr } \\
\text { am }\end{array}$ & 2 & Gender & .027 & 4.903 & 1 & Female \\
\hline
\end{tabular}

Growing Method: CHAID

Dependent Variable: which one do you prefer to use when communicating with Families?

a. Bonferroni adjusted

\begin{tabular}{|l|l|}
\hline \multicolumn{2}{|c|}{ Risk } \\
\hline Estimate & Std. Error \\
\hline .381 & .023 \\
\hline Growing Method: \\
CHAID \\
Dependent Variable: \\
which one do you \\
prefer to use when \\
communicating with \\
Families? \\
\hline
\end{tabular}

Classification

\begin{tabular}{|l|r|r|r|}
\hline Observed & \multicolumn{3}{|c|}{ Predicted } \\
\cline { 2 - 4 } & Facebook & Instagram & $\begin{array}{l}\text { Percent } \\
\text { Correct }\end{array}$ \\
\hline Facebook & 209 & 41 & $83.6 \%$ \\
Instagram & 130 & 69 & $34.7 \%$ \\
Overall & $75.5 \%$ & $24.5 \%$ & $61.9 \%$ \\
Percentage & & & \\
\hline
\end{tabular}

Growing Method: CHAID

Dependent Variable: which one do you prefer to use when communicating with Families? 


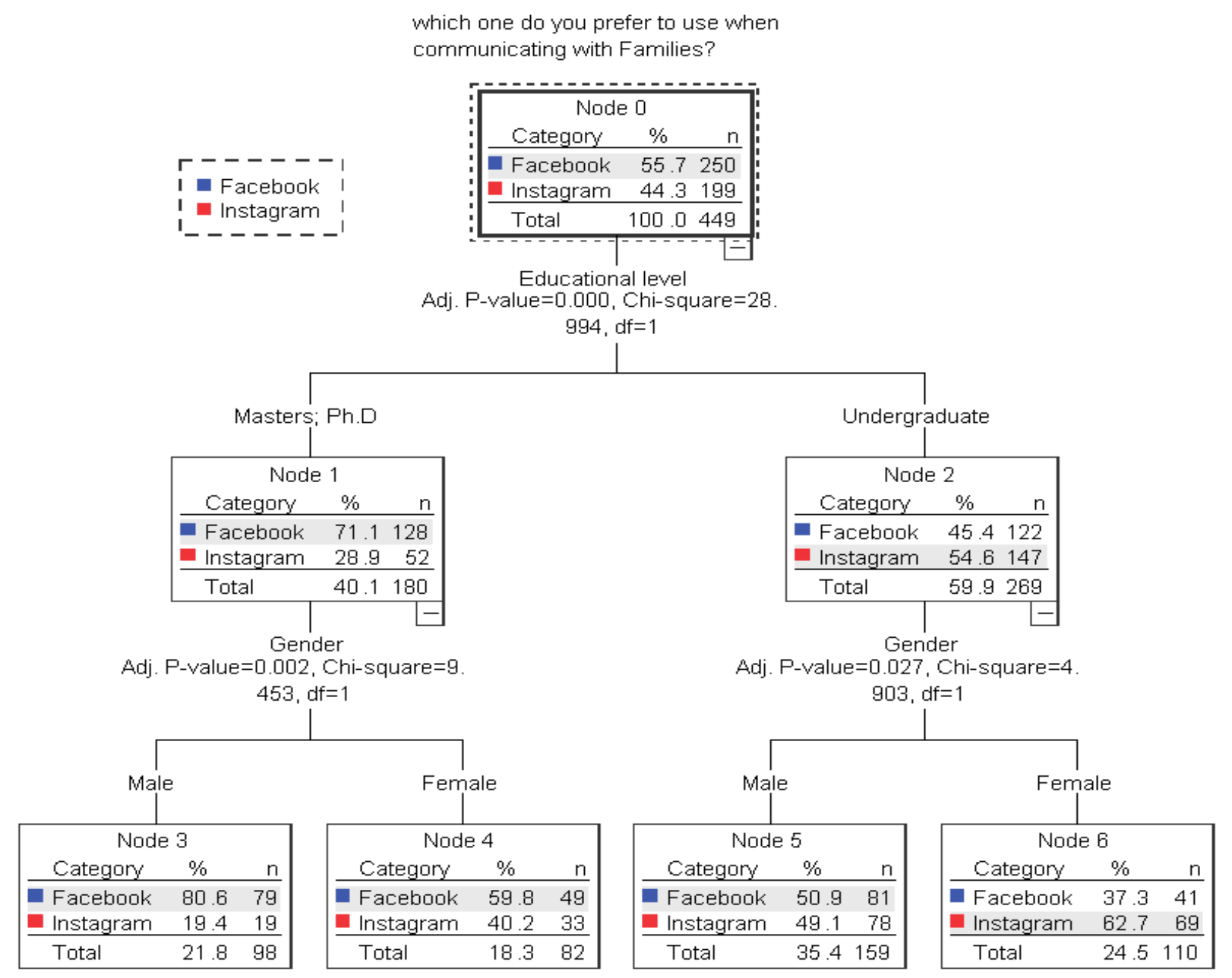

\section{Tree decision depicting the predictors when communicating with families (Educational factor and Gender are good predictors)}

Figure 1: Decision Tree for Social Media Preference to communicating with Family Members

Using the CHAID method, the tree diagram shows that educational level is the best predictor of the most preferred social media platform to communicate with families.

The tree shows that Educational level and Gender are best predictors of social media preference in communicating with families $(\mathrm{p}<0.05)$. The model shows that among Postgraduates students (Masters and $\mathrm{PhD}$ ), $71.10 \%$ of them prefer to use Facebook more in staying in touch with families while only $28.90 \%$ preferred to use Instagram and this difference is statistically significant $(\mathrm{p}<0.05)$. However, among undergraduate students, the undergraduate node revealed that $54.60 \%$ preferred to use Instagram while $45.40 \%$ preferred the usage of Facebook. The model shows that undergraduate students generally prefer to use Instagram platform to stay in touch with family members and this is statistically significant $(\mathrm{p}<0.05)$. The next best predictor in the model is gender. 
In the postgraduate student's category, the model revealed that both female $(80.60 \%)$ and male $(59.80 \%)$ postgraduate students have preference for Facebook usage than Instagram in communicating with their families with a statistical significance $(\mathrm{p}<0.05)$

\section{Research Question.2}

Research question two the best predictor when communicating with their international acquaintances results revealed as thus:

The model summary table indicates the independent variables used in the model and their significance. The table shows that marital status and gender significantly predict which social media platform is preferred in communicating with others (International acquaintances). Five independent variables were specified, but only two were included in the final model namely marital status and gender. The variables for age, educational level, and faculty, did not make a significant contribution to the model, so they were automatically dropped from the final model.

\section{Tree Table}

\begin{tabular}{|c|c|c|c|c|c|c|c|c|c|c|c|c|c|}
\hline \multirow{2}{*}{$\begin{array}{l}\text { Nod } \\
\mathrm{e}\end{array}$} & \multicolumn{2}{|c|}{ Facebook } & \multicolumn{2}{|c|}{ Instagram } & \multicolumn{2}{|c|}{ Total } & \multirow{2}{*}{\begin{tabular}{|c|} 
Predict \\
ed \\
Catego \\
ry \\
\end{tabular}} & \multirow{2}{*}{\begin{tabular}{|c|} 
Pare \\
nt \\
Nod \\
$\mathrm{e}$ \\
\end{tabular}} & \multicolumn{5}{|c|}{ Primary Independent Variable } \\
\hline & $\mathrm{N}$ & $\begin{array}{c}\text { Perce } \\
\text { nt }\end{array}$ & $\mathrm{N}$ & $\begin{array}{c}\text { Perce } \\
n t\end{array}$ & $\mathrm{~N}$ & $\begin{array}{c}\text { Perce } \\
\text { nt }\end{array}$ & & & $\begin{array}{c}\text { Varia } \\
\text { ble }\end{array}$ & Sig. ${ }^{\text {a }}$ & $\begin{array}{l}\text { Chi- } \\
\text { Square }\end{array}$ & $\mathrm{df}$ & Split Values \\
\hline 0 & $\begin{array}{r}16 \\
7\end{array}$ & $\begin{array}{r}37.2 \\
\%\end{array}$ & 282 & $\begin{array}{r}62.8 \\
\%\end{array}$ & $\begin{array}{r}44 \\
9\end{array}$ & $\begin{array}{r}100.0 \\
\%\end{array}$ & \begin{tabular}{|l} 
Instagr \\
am
\end{tabular} & & & & & & \\
\hline 1 & $\begin{array}{r}11 \\
9\end{array}$ & $\begin{array}{r}32.1 \\
\%\end{array}$ & 252 & $\begin{array}{r}67.9 \\
\%\end{array}$ & $\begin{array}{r}37 \\
1\end{array}$ & $\begin{array}{r}82.6 \\
\%\end{array}$ & $\begin{array}{l}\text { Instagr } \\
\text { am }\end{array}$ & 0 & $\begin{array}{l}\text { Marit } \\
\text { al } \\
\text { Statu } \\
\text { S } \\
\text { Marit }\end{array}$ & .000 & 23.950 & 1 & $\begin{array}{l}\text { Single; In a } \\
\text { relationship; } \\
\text { Divorced; Others }\end{array}$ \\
\hline 2 & 48 & $\begin{array}{r}61.5 \\
\%\end{array}$ & 30 & $\begin{array}{r}38.5 \\
\%\end{array}$ & 78 & $\begin{array}{r}17.4 \\
\%\end{array}$ & $\begin{array}{l}\text { Facebo } \\
\text { ok }\end{array}$ & 0 & $\begin{array}{l}\text { al } \\
\text { Statu } \\
\text { S }\end{array}$ & .000 & 23.950 & 1 & Married \\
\hline 3 & 81 & $\begin{array}{r}36.7 \\
\%\end{array}$ & 140 & $\begin{array}{r}63.3 \\
\%\end{array}$ & $\begin{array}{r}22 \\
1\end{array}$ & $\begin{array}{r}49.2 \\
\%\end{array}$ & $\begin{array}{l}\text { Instagr } \\
\text { am }\end{array}$ & 1 & $\begin{array}{l}\text { Gend } \\
\text { er }\end{array}$ & .022 & 5.254 & 1 & Male \\
\hline 4 & 38 & $\begin{array}{r}25.3 \\
\%\end{array}$ & 112 & $\begin{array}{r}74.7 \\
\%\end{array}$ & $\begin{array}{r}15 \\
0\end{array}$ & $\begin{array}{r}33.4 \\
\%\end{array}$ & $\begin{array}{l}\text { Instagr } \\
\text { am }\end{array}$ & 1 & $\begin{array}{l}\text { Gend } \\
\text { er }\end{array}$ & .022 & 5.254 & 1 & Female \\
\hline
\end{tabular}

Growing Method: CHAID

Dependent Variable: which one do you prefer to use when communicating with others? International acquaintances?

a. Bonferroni adjusted

\section{Risk}

\begin{tabular}{|r|r|}
\hline Estimate & Std. Error \\
\hline .332 & .022 \\
\hline
\end{tabular}


Volume 1 Number 2

Growing Method:

CHAID

Dependent Variable: which one do you prefer to use when communicating with others? International acquaintances?

\section{Classification}

\begin{tabular}{|l|r|r|r|}
\hline Observed & \multicolumn{3}{|c|}{ Predicted } \\
\cline { 2 - 4 } & Facebook & Instagram & $\begin{array}{l}\text { Percent } \\
\text { Correct }\end{array}$ \\
\hline Facebook & 48 & 119 & $28.7 \%$ \\
Instagram & 30 & 252 & $89.4 \%$ \\
Overall & $17.4 \%$ & $82.6 \%$ & $66.8 \%$ \\
Percentage & & & \\
\hline
\end{tabular}

Growing Method: CHAID

Dependent Variable: which one do you prefer to use when communicating with others? International acquaintances? 
NNAMDI AZIKIWE UNIVERSITY Journal of COMMUNICATTON AND MEDLA STUDIES

Volume 1 Number 2

Which one do you prefer to use

when communicating with others?

International acquaintances?
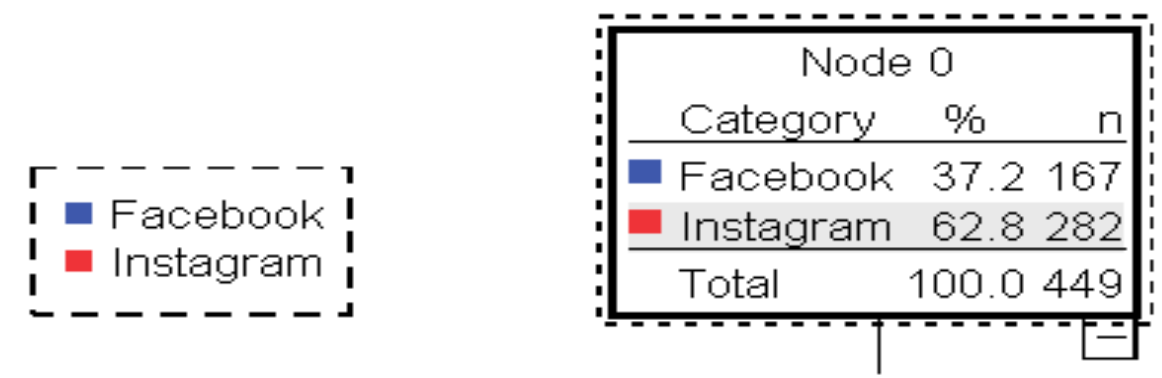

Marital Status

Adj. P-value=0.000, Chi-square=23.

950, $d f=1$

Single; In a relationship; Divorced; Others

\begin{tabular}{|c|c|c|}
\hline \multicolumn{3}{|c|}{ Node 1} \\
\hline Category & $\%$ & $\mathrm{n}$ \\
\hline - Facebook & 32.1 & $\begin{array}{l}119 \\
252\end{array}$ \\
\hline Total & 82.6 & 371 \\
\hline
\end{tabular}

\begin{tabular}{|c|c|c|}
\hline \multicolumn{3}{|c|}{ Node 2} \\
\hline Category & $\%$ & $\mathrm{n}$ \\
\hline Facebook & 61.5 & 48 \\
\hline ㅁ Instagram & 38.5 & 30 \\
\hline Total & 17.4 & 78 \\
\hline
\end{tabular}

Adj. P-value $=0.022$, Chi-square $=5$.

254, $d f=1$

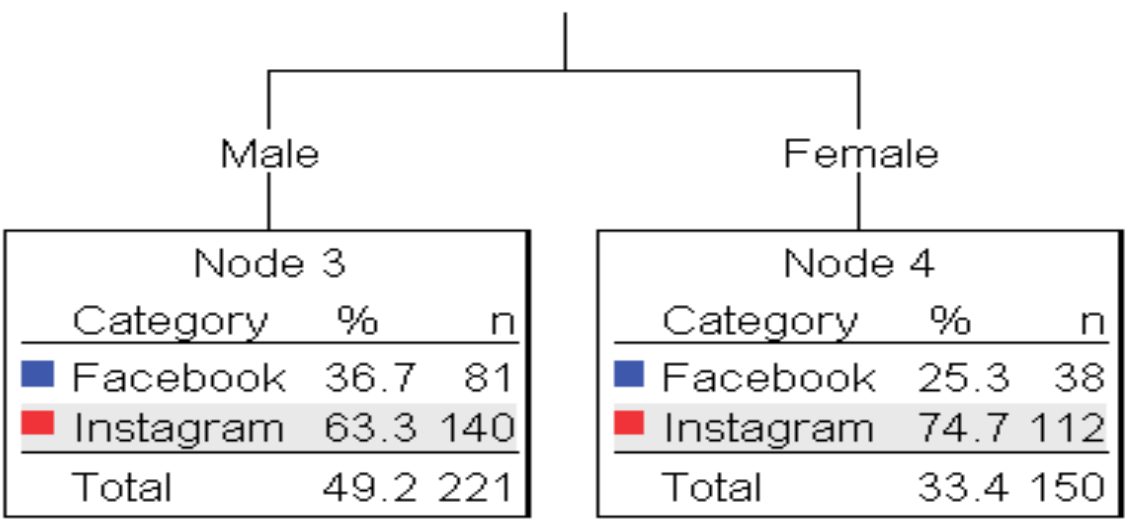

Decision Tree for Social Media Preference to communicating with others (International acquaintances) 
Using the CHAID method, the tree diagram shows that marital status and gender were the best predictor of the most preferred social media platform to communicate with international acquaintances.

The tree shows that marital status and gender are best predictors of social media preference in communicating with others $(\mathrm{p}<0.05)$. The model shows an immediate two nodes division. The first node comprises the singles, people in a relationship, divorcee and others while the second node comprises the married. Among the singles, people in a relationship, divorcee and others, larger percentage of them $(67.90 \%)$ have greater preference to use Instagram in communicating with international acquaintances while married individuals $(61.50 \%)$ preferred to use Facebook in communicating with international acquaintances. Since there are no child nodes below the married category, it is considered a terminal node.

However, a further statistically significant predictor for the singles, people in a relationship, divorcee and others category is the gender variable $(\mathrm{p}<0.05)$. In this aforementioned category, the males (63.30\%) preferred using Instagram as well as the females $(74.70 \%)$ in communicating with international acquaintances.

\section{Risk}

\begin{tabular}{|l|r|}
\hline Estimate & Std. Error \\
\hline .332 & .022 \\
\hline Growing Method: \\
CHAID \\
Dependent Variable: \\
which one do you \\
prefer to use when \\
communicating with \\
others? International \\
acquaintances? \\
\hline
\end{tabular}

\section{Classification}

\begin{tabular}{|l|r|r|r|}
\hline Observed & \multicolumn{3}{|c|}{ Predicted } \\
\cline { 2 - 4 } & Facebook & Instagram & $\begin{array}{l}\text { Percent } \\
\text { Correct }\end{array}$ \\
\hline Facebook & 48 & 119 & $28.7 \%$ \\
Instagram & 30 & 252 & $89.4 \%$ \\
Overall & $17.4 \%$ & $82.6 \%$ & $66.8 \%$ \\
Percentage & & & \\
\hline
\end{tabular}

Growing Method: CHAID

Dependent Variable: which one do you prefer to use when communicating with others? International acquaintances?

The risk estimate of 0.332 indicates that the category predicted by the model (Facebook or Instagram) is wrong for $33.20 \%$ of the cases. So the "risk" of misclassifying a respondent is approximately $33 \%$. The results in the classification table are consistent with the risk estimate. The classification table shows that the model classifies approximately $67 \%$ of the participants correctly. 
Base on the result from the analysis, education is the best predictor when two platforms are posed for consideration. In a related research conducted on demographic variables and the use of SNS, when testing belief and attitudes in use, their results revealed that demographic variables are connected with attitude disparity and differences in users'belief (Lennon, Rentfro, \& Curran, 2012). Thus the work revealed that education and gender are also predictors to preference of sites when selecting a specific network and communication with ones' family by students.

Although there are other demographic factors that are used for the analysis when communicating with other international acquaintances, marital status serves as the best indicator and also gender, but the strongest is marital. There is correlation between communication skills and adjustment by the married (AhmadiGatab, \&Khamen, 2011). The different marital levels posed for the research such as singles, in a relationship, divorce and the married have some disparity in levels they engage in communication with international acquaintances. In addition, gender serves as an indicator that based on the axiom of the uncertainty reduction theory and these two, "marital status and gender" may serve as a signal of whom to disclose ones identity to. Hence, self-disclosure is very essential that you may choose whom to disclose your personal information to. Consequently, people operate at different perspectives based on belief and so forth, thus female may be attracted to female while men may be attracted to men too, buttressing a point on "similarity" and "liking".Thus they are essential with new axioms that are added in the theory which is "communication satisfaction" thus axioms 8 works (Redmond, 2015).

\section{CONCLUSION AND RECOMMENDATIONS}

The place of prediction is an essential aspect that needs to be utilized in communication especially the type that has to do with different races, gender, and different marital status. It can be used to determine the level of relationship, but the use of platforms comes with different affordances which make users to select a network of their choice. Many factors could be responsible for such choices hence in future research, there may be need to get the right predictor that will serve as a guide for the work researchers will want to conduct for this will make their work a bit easier.

Future research can concentrate on the reasons why when communicating with families; educational levels play a major role for preference of sites and also the students' gender. In addition the use of gender that predicts preference can be put into cognizance hence other demographic factors that are used will be reworked on in a different location to determine the acceptance of this result. This can be achieved when another method or approaches are adopted, hence the need for longitudinal studies.

\section{REFERENCES}

Abdulbaqi, S. S. \&Arikewuyo, A. O. (2013). The broadcast media and sustainability of peace in Ilorin: An assessment of the impact of radio and television. In A. A. Oladosu., Z. I. Oseni.\& M. A.Adedimeji (Eds.). History, Culture and Lessons of Peaceful CoExistence (p. 244-257). Ilorin: Centre For Ilorin Studies

Agresti, A. B. (2008). Statistical Options for the Social Sciences (4th ed.). New Jersey:

Prentice Hall.

AhmadiGatab, T., \&Khamen, A. B. Z. (2011).Relation between communication skills and marital-adaptability among university students. Procedia-Social and Behavioral Sciences, 30, 1959-1963. 
Aksoy, L., Van Riel, A., Kandampully, J., Bolton, R. N., Parasuraman, A., Hoefnagels, A., ...\&Solnet, D. (2013). Understanding Generation Y and their use of social media: a review and research agenda. Journal of service management.

Alhabash, S., \& Ma, M. (2017). A tale of four platforms: Motivations and uses of Facebook, Twitter, Instagram, and Snapchat among college students?. Social Media+ Society, 3(1), 2056305117691544.

Barr, S., (2018). The story of how Facebook was created in a Harvard dorm room. Retrieved 5 November 2019, from https://www.independent.co.uk/life-style/gadgets-andtech/facebook-when-started-how-mark-zuckerberg-history-harvard-eduardo-saverina8505151.html

Bellis, M., (2019). The History of How Mark Zuckerberg Invented Facebook. Retrieved 5 November 2019, from https://www.thoughtco.com/who-invented-facebook1991791

Bicen, H., \& Cavus, N. (2010). The most preferred social network sites by students. Procedia-Social and Behavioral Sciences, 2(2), 5864-5869.

Clark, J. L., Algoe, S. B., \& Green, M. C. (2018). Social network sites and well-being: the role of social connection. Current Directions in Psychological Science, 27(1), 32-37.

De Dreu, C. K., Nijstad, B. A., \& Van Knippenberg, D. (2008).Motivated information processing in group judgment and decision making. Personality and social psychology review, 12(1), 22-49.

Dillman , D. A., Smyth, J. D., \& Christian , L. M. (2014). Internet, Phone, Mail and Mixed Mode Surveys. Hoboken New Jersey: John Wiley and Sons incorpporated.

DUGGAN, M., (2015).Demographics of Social Media Users in 2015. Retrieved 5 December 2019, from https://www.pewresearch.org/internet/2015/08/19/the-demographics-ofsocial-media-users/

DUGGAN, M., BRENNER, J., (2013).The Demographics of Social Media Users - 2012. Retrieved $\quad 5 \quad$ December $2019, \quad$ from https://www.pewresearch.org/internet/2013/02/14/the-demographics-of-social-mediausers-2012/

Froget, J. R. L., Baghestan, A. G., \&Asfaranjan, Y. S. (2013).A uses and gratification perspective on social media usage and online marketing. Middle-East Journal of Scientific Research, 15(1), 134-145.

Garcia-domingo, M., Aranda, M., \& Fuentes, V. M. (2017). Facebook use in university students: Exposure and reinforcement search. Procedia-Social and Behavioral Sciences, , 237, 249-254.

Greiner, A., Fiegerman, S., Sherman, I., Baker, T., (2019). Facebook at 15: How a college experiment changed the world. Retrieved 5 November 2019, 
Volume 1 Number 2

https://edition.cnn.com/interactive/2019/02/business/facebook-historytimeline/index.html

Hall, M., (2019).Facebook | Overview, History, \& Facts. Retrieved 5 November 2019, from https://www.britannica.com/topic/Facebook

Hinsz, V. B. (1999). Group decision making with responses of a quantitative nature: The theory of social decision schemes for quantities. Organizational behavior and human decision processes, 80(1), 28-49.

Huang, Y. T., \& Su, S. F. (2018).Motives for instagram use and topics of interest among young adults. Future Internet, 10(8), 77.

Hughes, D. J., Rowe, M., Batey, M., \& Lee, A. (2012). A tale of two sites: Twitter vs. Facebook and the personality predictors of social media usage. Computers in Human Behavior, 28(2), 561-569.

Kaplan, M. F., \& Miller, C. E. (1987). Group decision making and normative versus informational influence: Effects of type of issue and assigned decision rule. Journal of Personality and social psychology, 53(2), 306.

Kircaburun, K., Alhabash, S., Tosuntaş, Ş. B., \& Griffiths, M. D. (2018). Uses and gratifications of problematic social media use among university students: A simultaneous examination of the Big Five of personality traits, social media platforms, and social media use motives. International Journal of Mental Health and Addiction, 1-23.

Korhan, O., \&Ersoy, M. (2016). Usability and functionality factors of the social network site application users from the perspective of uses and gratification theory. Quality \& Quantity, 50(4), 1799-1816.

Krejcie, R. V., \& Morgan, D. W. (1970). Determining sample size for research activities. Educational and psychological measurement, 30(3), 607-610.

LaRose, R., \& Eastin, M. S. (2004). A social cognitive theory of Internet uses and gratifications: Toward a new model of media attendance. Journal of Broadcasting \& Electronic Media, 48(3), 358-377.

Lennon, R., Rentfro, R. W., \& Curran, J. M. (2012).Exploring relationships between demographic variables and social networking use. Journal of Management and Marketing Research, 11, 1.

Milanović, M., \&Stamenković, M. (2016). CHAID decision tree: Methodological frame and application. Economic Themes, 54(4), 563-586.

McFadden, C., (2019). A Brief History of Facebook, Its Major Milestones. Retrieved 5 November 2019, from https://interestingengineering.com/history-of-facebook

Phillips, S., (2007).A brief history of Facebook. Retrieved 5 November 2019, from https://www.theguardian.com/technology/2007/jul/25/media.newmedia 
Volume 1 Number 2

Ponto, J. (2015). Understanding and Evaluating Survey Research. Journal of the Advanced Practitioner in Oncology, 6(2), 168-171.

Redmond, Mark V., "Uncertainty Reduction Theory" (2015). English Technical Reports and White Papers. 3.https://lib.dr.iastate.edu/engl_reports/3

Saul, R. (2016). Education and the mediated subject: what today's teachers need most from researchers of youth and media. Journal of Children and Media, 10(2), 156-163.

Taherdoost, H. (2017). Determining sample size; how to calculate survey sample size. International Journal of Economics and Management Systems, 2.

Whiting, A., \& Williams, D. (2013). Why people use social media: a uses and gratifications approach. Qualitative Market Research: An International Journal.

Woods, B., (2013). Instagram - A Brief History. Retrieved 21 November 2019, from https://thenextweb.com/magazine/2013/06/21/instagram-a-brief-history/ 